\title{
Effect of Antagonists and Plant Extracts in the Control of Protea Wilt (F, oxysporum)
}

\author{
Edgar Martínez Granja*, Sergio Reyes Benitez, Danny Sanjuanello \\ Facultad de Ingeniería Agronómica, Universidad de Ciencias Aplicadas y Ambientales, Bogotá, Colombia \\ Email: ${ }^{*}$ edgamartinez@udca.edu.co
}

Received 2 August 2014; revised 12 September 2014; accepted 17 October 2014

Copyright $\odot 2014$ by authors and Scientific Research Publishing Inc.

This work is licensed under the Creative Commons Attribution International License (CC BY). http://creativecommons.org/licenses/by/4.0/

(c) (;) 0pen Access

\begin{abstract}

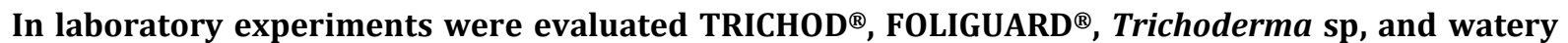
extracts of pine, marigold and eucalyptus, respectively, against $F$. oxysporum. There were no significant differences between TRICHOD $^{\circledR}$ and FOLIGUARD ${ }^{\circledR}$. The extract of marigold of $120 \mathrm{~g} / \mathrm{L}$ was the best result in reducing the area of the colony of $F$. oxysporum. In field pots experiment were evaluated the extract of marigold $(120 \mathrm{~g} / \mathrm{L})$, potassium phosphite $(400 \mathrm{~g} / \mathrm{L})$, TRICHOD and benomyl $(1.5 \mathrm{~g} / \mathrm{L})$ to control $F$. oxysporum. Treatments were applied to the soil, 15 days after inoculation with $F$. oxysporum. The best obtained heights were of $32 \mathrm{~cm}$ with extract of marigold 120 $\mathrm{g} / \mathrm{L}$, followed by potassium phosphite with $31 \mathrm{~cm}$, and the control reached $26 \mathrm{~cm}$ of height. The treatment with an extract of marigold $120 \mathrm{~g} / \mathrm{L}$, obtained the best dry weight average of $6.5 \mathrm{~g}$, statistically different from the control. The extract of marigold presented the best efficiency against the disease, because it reduced the length of the vascular symptom in $88.5 \%$; followed by TRICHOD ${ }^{\circledR}$, benomyl and potassium phosphite that showed reductions of 86,85 and 84 percent, respectively.
\end{abstract}

\section{Keywords}

Marigold Extract, Plant Disease Control, Trichoderma

\section{Introduction}

The diversification in planting ornamental species has been a strategy used by the producers, as an alternative to extending markets, to improve competitiveness and to increase profitability. A step in this respect has been the production and commercialization of new flowers and foliages, as the proteas of the genus Leucadendron.

The cultivation of proteas is relatively new in the market of ornamental plants for the production of flowers,

${ }^{*}$ Corresponding author. 
dried flowers and flower pots [1]. There is great diversity of proteas and the genus Leucadendron has stand out in international trade, mainly in the European community, as cut and processed as dried flower blossom. The main consumers of proteas are Japan, Europe and the United States. This market has an estimated value of 455 million euros. The total number of stems exported around the world is 100 million units and about half of total world exports are of the genus Leucadendron [2].

Proteas production has been affected by the incidence of diseases caused by three pathogens of great importance that inhabit the soil: Phytophthora cinnamomi, Rhizoctonia spp. and Fusarium spp. [3]-[5]. In the genus Fusarium three species are agents of Leucadendron wilt: F. oxysporum, F. solani and F. moniliforme. F. oxysporum was first detected in the northwestern region of South Africa and Zimbabwe [6]. It has subsequently been reported in different parts of the world where proteas are cultivated and it was reported the incidence of $F$. sola$n i$ and F. equiseti attacking proteas of the genus Leucandendron especially in the Madeira Island in Portugal [3]. It has also been found in the Canary Islands [7] and in Australia [8]. In Australia, was found F. oxysporum in roots, neck and vascular tissue of plants with wilt symptoms [9]. Also, has been detected in seedlings and commercial plantations, causing losses greater than $60 \%$ [8]-[10].

In Colombia, F. oxysporum is the causal agent of Leucadendron wilt [1]. Symptoms have been observed in young and adult plants of the protea cultivars Petra and Gold Strike. Necrosis was observed at the beginning in young leaves and side shoots that die after infection, generating a reduction in the number of flowers produced per plant [6]-[8]. Vascular tissues acquire a dark brown color which extends from the root to the stem of the plant and affects both the xylem and phloem. There is a turgor loss in the apical part of the shoot, yellowing occurs from the lower leaves towards the top of the branch. Subsequently, the branches weaken and necrosis appears in leaves and the stem [1].

In general, the diseases caused by F. oxysporum are difficult to control. Resistant varieties, planting certified seeds, and healthy seedlings are the best practices to control wilt caused by Fusarium species. Also antagonist biocontrol agents, such as Trichoderma, offer possibilities to control, primarily because it inhibits the growth and development of the disease [11]. The genus Trichoderma has fast reproduction; it is able to survive and to modify the rhizosphere and it is effective in promoting plant growth [12]. The incidence of proteas wilt was reduced to $20 \%$ by using a native strain of $T$. harzianum in concentrations of $10^{8}$ and $10^{9}$ conidias per mL [7]. Tricoderma has been commercially produced to be used in controlling several plant pathogens such as: Pythium spp, Rhizoctonia spp, Sclerotium spp, and Fusarium spp [13].

A variety of Trichoderma species has been evaluated to control $F$. oxysporum in different crops. To control this pathogen in papaya plants (Carica papaya L.) a treatment of Trichoderma at a concentration of $10^{6}$ conidia wasapplied to the soil artificially infested with $F$. oxysporum. Its antagonist effect has also been evaluated on tomato plants to wilt caused by $F$. oxysporum [14].Tomato seeds coated with $T$. harzianum were planted in natural soil artificially infested with F. oxysporum [15]. The seed treatment caused no reduction in the disease, whereas the soil treatment was able to reduce $92 \%$ of the infection. In Cuba T. harzianum applied $20 \mathrm{~g} / \mathrm{plant}$ in soils with occurrence of Panama disease, provided superior control to 95\% in the varieties tested [16].

In searching for new alternatives to organic plant disease management, the use of plant metabolites has been considered feasible [17]. Botanical pesticides are chemical compounds that occur naturally in plants. They have been used to reduce the growth of certain fungi under laboratory conditions. Extracts of eucalyptus and other plants in different concentrations reduced the growth of $F$. solani. The marigold (Calendula officinalis) is cultivated in different countries, and some studies have been developed using this plant extractto control some species of nematodes that attack citrus, but its greatest use has been in human dermatology and food industry, due to its antimicrobial properties [18] [21]. Essential oils are extracted from roots, seeds, leaves and flowers of marigold, which are rich in sesquiterpenes, phenols and saponins that are responsible for the antifungal activity [22]. Sesquiterpenes activity was evaluated in vitro for control C. acutatum, C. fragariae, C. gloesporoides, F. oxysporum, Botrytis cinerea, and Phomopsis sp [23].

In Colombia, the growers apply some chemical fungicides, such as benomyl to wilt control. This product reduced by $50 \%$ the incidence of wilt caused by $F$. oxysporum on susceptible tomato plants [24]. Similar results were obtained in tomato [25] and susceptible native bean varieties planted in soil naturally infested with Fusarium spp and Rhizoctonia solani [26]. Also it reduced the Panama disease (F. oxysporum. f. sp. cubense) in banana by $70 \%$ with a drench application one week after transplantation was made [27]. According to Obreque [7] benomyl has been widely used in the preventive control of wilt of proteas in South Africa.

The antimicrobial properties of the phosphites were found in studies aimed at controlling diseases caused by 
oomycetes [28] [29]. Also, Mogollón and Castaño [30], showed the effect of potassium phosphite as resistance inductor, when it was applied to the soil to control sigatoka disease caused by M. fijiensis and M. musicola in plantains. And Walters et al., [31] demonstrated the effectiveness of potassium phosphiteto control different diseases, including those caused by Phytophthora infestans, Fusarium oxysporum and Rhizoctonia solani. It was found that the foliar application of potassium phosphite reduced by $40 \%$ the severity of wheat wilt caused by $F$. culmorum [32].

The main objective of this research was to determine the effect of Trichoderma spp, potassium phosphite, benomyl and plant extracts in the control of $F$. oxysporum in Leucadendron proteas, in laboratory and field pot conditions.

\section{Materials and Methods}

\subsection{Laboratory Experiments}

F. oxysporum was isolated from diseased Leucadendron proteas collected in established crops, in a farm located in Subachoque, Department of Cundinamarca, Colombia, at 2600 altitude, and temperature between $15^{\circ} \mathrm{C}$ and $19^{\circ} \mathrm{C}$. Wilty Petra variety plants were chosen with external and internal symptoms. The fungus was isolated in acidified Potato Dextrose Agar (PDA + A) with $2500 \mu \mathrm{L}$ of 50\% lactic acid per $1000 \mathrm{~mL}$ of medium. Stem samples with visible wilt symptoms were previously washed with tap water to remove soil residues. Of each stem, square $5 \mathrm{~mm}$ pieces were cut, and immersed $1 \mathrm{~min}$ in $70 \%$ ethanol, two minutes in sodium hypochlorite 1\% and washed in sterile distilled water for $30 \mathrm{~s} \mathrm{[33].} \mathrm{In} \mathrm{a} \mathrm{laminar} \mathrm{flow} \mathrm{cabinet,} \mathrm{four} \mathrm{pieces} \mathrm{were} \mathrm{planted} \mathrm{on} \mathrm{each}$ Petri dish containing PDA + A using a sterilized forceps. The isolated samples were incubated at $20^{\circ} \mathrm{C}$ for eight days. On slides, stained with lactophenol cotton blue, were examined at light optical microscope (Nikon eclipse E 100) at $40 \times$ and $100 \times$ to check the morphological characteristics of the pathogen, by comparison with diagrammatic keys [34] [35].

Data from each of the two laboratory experiments, were processed with the SAS statistical program, through which the fulfillment of assumptions prior to the execution of the analysis of variance was tested. In cases where the F-test analysis of variance was significant, the honest Tukey multiple comparison (Tukey HSD) was used to determine the differences within treatments.

Experiment 1. The TRICHOD ${ }^{\circledR}$ (Orius Biotecnologia) and FOLIGUARD ${ }^{\circledR}$ (Live Systems Technology) commercial biological products with the active ingredient Trichoderma harzianum and an isolate of Trichoderma sp uncharacterized, were evaluated against $F$. oxysporum using spore suspensions at a concentration of $1 \times$ $10^{8}$ spores $/ \mathrm{mL}$. A completely randomized design was followed, with 15 replications, where each treatment corresponded to a biological product. Two discs of $8 \mathrm{~mm}$ diameter, one of the pathogens and one of the antagonists, were transferred to a Petri dish with PDA + A. These discs were located one in front of the other at a distance of $3 \mathrm{~cm}$, and were incubated at $20^{\circ} \mathrm{C}$. The pathogen area growth in each treatment, and the control without treatment was measured three times at week for a period of three weeks.

Experiment 2. In order to set the action of plant extracts of pine, eucalyptus and marigold on the development of colonies of F. oxysporum, the next procedure was followed: Samples of these plant species were collected in the campus of UDCA, washed with water, immersed in sodium hypochlorite $1 \%$ for two minutes, and finally rinsed with sterile distilled water. Three subsamples of $60 \mathrm{~g}, 120 \mathrm{~g}$ and $180 \mathrm{~g}$, for each one of pine, eucalyptus and marigold samples, respectively, were evaluated. Each subsample was boiled in a liter of sterile distilled water and subsequently filtered through filter paper, adjusted to $1000 \mathrm{ml}$ of water to prepare a culture medium PDA + A + Extract (PDA + A + E).

From the pure culture of $F$. oxysporum obtained in experiment 1,15 discs of $8 \mathrm{~mm}$ in diameter were extracted and planted in individual petri dishes containing the PDA $+\mathrm{A}+\mathrm{E}$ culture medium, and incubated at $20^{\circ} \mathrm{C}$. The colony area was measured three times a week for a period of three weeks. It was followed a completely randomized design with 15 replications for each extract and concentration.

\subsection{Field Pots Experiment}

Leucadendron proteas plants, cultivar "Safari Sunset", one month old at the time of transplantation, with no internal and external disease symptoms were planted in $5 \mathrm{~kg}$ pots, filled with unsterilized soil obtained in the experimental field of UDCA. Once planted they were located according to the experimental design in rows of 10 
pot plants per each of the five treatments, spaced $0.30 \mathrm{~m}$ apart.

Then, a randomized complete block design was followed with five treatments and five replications. The treatments were $T$. harzianum, marigold plant extract $120 \mathrm{~g} / \mathrm{L}$, potassium phosphite, benomyl $50 \mathrm{WP}$, and the absolute control. The treatments had randomization within the blocks and in the experimental area. Each experimental unit consisted of 10 plants for a total of 250 plants. For data analysis, the Minitab 16 statistical software was used.

To isolate $F$. oxyporum it was followed the procedure previously described. Ten days after planting, the seedlings were inoculated with a suspension of $10^{6}$ macroconidia/mL of $F$. oxysporum [Salazar et al., 2010]. One $\mathrm{mL}$ of the suspension was injected into the root collar, using a plastic syringe. Fifteen days after the inoculation the following treatments were applied: 1) $5 \mathrm{~mL}$ per pot around the plant of a suspension of TRICHOD ${ }^{\circledR}$ at a concentration of $2 \times 10^{10}$ conidia/mL of $T$. harzianum; 2 ) This treatment consisted of the application of $10 \mathrm{~mL}$ of marigold extract, around the neck of the plant. The marigold extract was prepared with $120 \mathrm{~g}$ of marigold leaves per liter of water, because the best results were obtained in the laboratory study; 3) For the treatment with the fungicide the product benomyl $50 \mathrm{WP}$ was used in doses of $1.5 \mathrm{~g}$ per liter of water. Two $\mathrm{mL}$ of the solution were used to drench the soil around the stem in each plant; 4) To evaluate the potassium phosphitethe commercial product Agrifos $400 \mathrm{SL}$, was used. The drench had a concentration of $7.5 \mathrm{~mL}$ of the commercial product per liter of water. Each plant was drenched with $5 \mathrm{~mL}$ of this solution; 5) The control did not receive chemical nor biological treatments.

For six months, every 15 days data were taken in five randomly selected plants in each treatment and replications. a) The height of the plant was measured between the soil surface and the apex of the last leaf of the plant with a ruler; b) The number of side shoots was quantified; c) At the end of six months, no external symptoms of the disease manifested and for this reason destructive sampling was performed in order to observe wilt symptoms in the vascular bundles of the plant. Dry matter accumulation was determined in the roots of the plants selected at random, in the destructive sampling. Fresh weight was taken and then placed in an oven for 48 hours at $60^{\circ} \mathrm{C}$, to obtain dry weight. Five plants per treatment were evaluated, totaling 25 plants. For data analysis the Minitab 16 statistical software was used and the data were subjected to analysis of variance, Tukey test and the examination of contrasts.

\section{Results and Discussion}

\subsection{Experiments at Plant Pathology Laboratory}

Significant differences were found $(\mathrm{p}<0.01)$ among three treatments: TRICHOD ${ }^{\circledR}$, FOLIGUARD ${ }^{\circledR}$ and Trichoderma sp, and the control. In general, they reduced the growth of the F. oxysporum colony. Duncan test indicates that TRICHOD ${ }^{\circledR}$ reduced significantly the colony area of $F$. oxysporum, followed by FOLIGUARD ${ }^{\circledR}$ and Trichoderma sp (Figure 1).

The results indicate that Trichoderma inhibits colony growth of $F$. oxysporum under laboratory conditions. This antagonistic effect has already been described by other researchers to explain the potential of the genus Trichoderma for the management of this important plant pathogen. Cifuentes [36] found that $T$. harzianum was

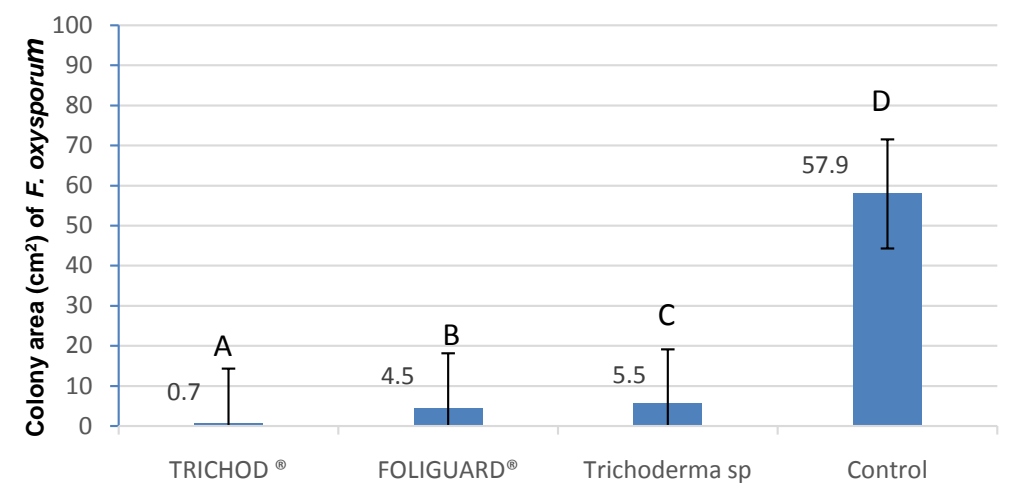

Figure 1. Effect of TRICHOD ${ }^{\circledR}$, FOLIGUARD ${ }^{\circledR}$ and Trichoderma sp on the colony area of $F$. oxysporum. Means of 15 replications. Means with the same letter are not significantly different by the Duncan test. 
highly effective in controlling Fusarium solani in tomato. Also, when the chemical control and the use of antagonists against $F$. graminearum were compared, it was determined that copper oxychloride inhibited growth of the pathogen, whereas Trichoderma reduced 64\% the colony growth and was effective in reducing the severity of the disease in wheat crops [37]. Meanwhile, it was established [16] that T. harzianum obtained 95\% control in plantations of banana affected by Panama disease.

According to Stefanova et al., [38] and Selosse et al., [39], the activity and biocontrol efficacy of Trichoderma is based on the property to act directly as hyperparasite, and indirectly by means of the action of antifungal metabolites and hydrolytic enzymes that cause cellular changes in the pathogen, and may cause degradation of the cell wall of F. oxysporum. These characteristics of Trichoderma will increase their competitiveness and effectiveness in controlling other pathogens that inhabit the soil.

The tested plant extracts showed significant differences $(\mathrm{p}<0.01)$ among treatments (Figure 2) and reduced the colony area of $F$. oxysporum and best results were found with marigold extract. The three concentrations evaluated were significantly different from other treatments and the control, but no statistical differences were found between the three concentrations of marigold. Treatment corresponding to $120 \mathrm{~g}$, had the lowest growth area of $F$. oxysporum. No differences were found between pine and eucalyptus extracts and the control.

There is a possibility of using plant extracts to control plant pathogens. In coffee plants promising results have been obtained in the management of diseases because of their mechanism of direct action on pathogens, and their potential for inducing systemic resistance [40]-[43]. The antimicrobial action of marigold extract is linked to the production of secondary metabolites content in vegetables such as flavonoids, salicylic acid, sesquiterpenes and phenols [23]. For example, phenols, are toxic against Fusarium species [41]. Eucalyptus extract has been found to reduce the growth of mycelium of Colletotrichum, but no effects on Fusarium are known [42].

The results explore the possibility of new organic technologies that allow a sustainable management of plant health problems, which counteract the harmful effects of the use of synthetic chemical fungicides. New technologies are a common benefit to produce proteas and other crops where Fusarium attacks generate large losses. Moreover, the results are a significant contribution to knowledge and use of biodiversity, because working with native and introduced plants, and domesticated microorganisms in Colombia generate knowledge to expand their potential uses.

\subsection{Field Pots Experiment}

Plant height. The data were transformed, and significant differences $(p<0.001)$ among treatments and blocks were found. The heights were $31 \mathrm{~cm}$ and $32 \mathrm{~cm}$ between plants treated with potassium phosphite and plants treated with marigold extract, respectively. These results were statistically different to the control (Figure 3). Theapplication of benomyl, could have an initial effect on the incidence of the disease, but was not persistent

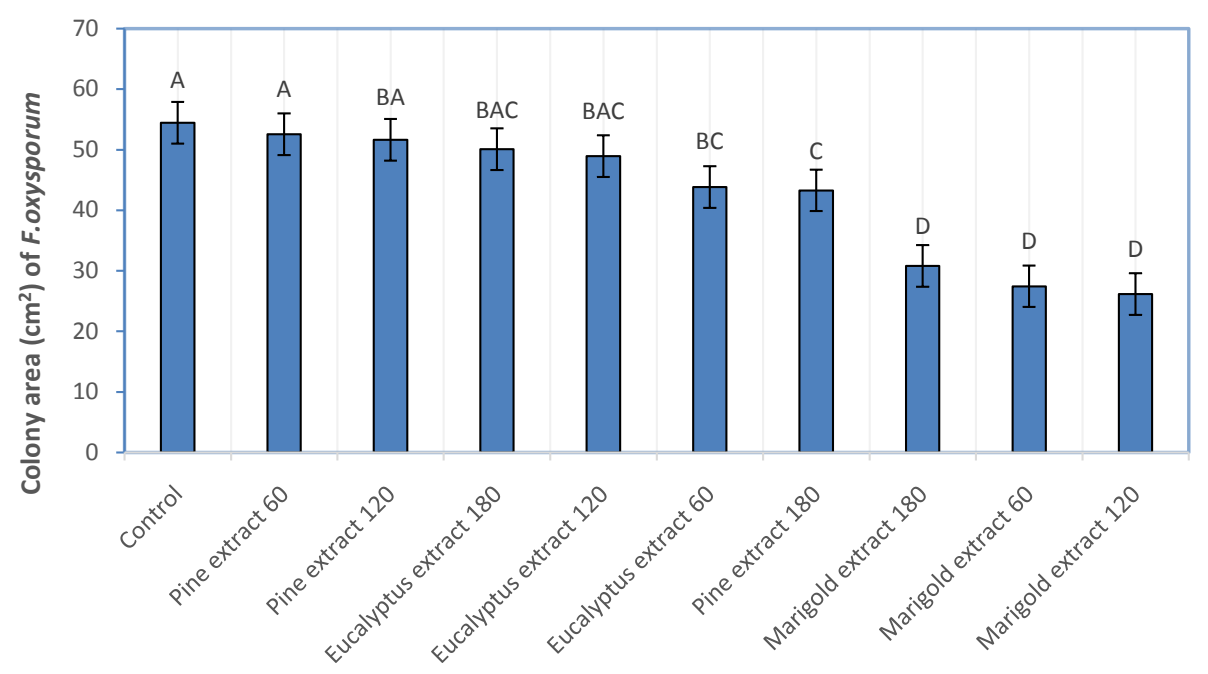

Figure 2. Effect of pine, eucalyptus and marigold extracts on the colony area of F. oxysporum. Means of 15 replications. Means with the same letter are not significantly different by the Duncan test. 


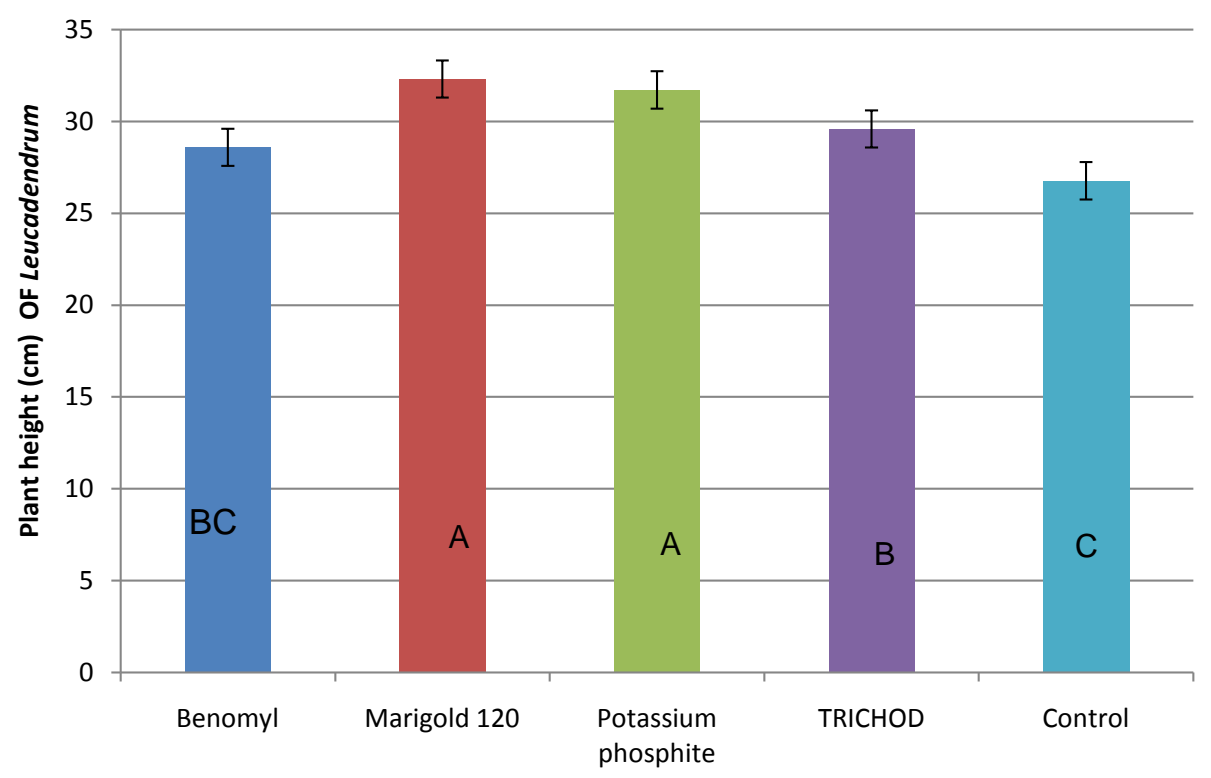

Figure 3. Effect of benomyl, marigold 120, potassium phosphite and TRICHOD on plant height of Leucadendrum. Means of 5 replications. Means with the same letter are not significantly different by the Tukey test.

enough to allow normal plant development. The control presented a marked delay in growth with $26 \mathrm{~cm}$ and development compared to treated plants.

Number of side shoots. There were no significant differences $(\mathrm{p} \leq 0.05)$ among the treatments: TRICHOD, potassium phosphite, marigold extract and benomyl. However, there were differences between these treatments and the control. The greatest number of side shoots was 2.5 occurred with the TRICHOD ${ }^{\circledR}$ treatment (Figure 4). Avis et al., (2008) highlights the action of Trichoderma not only as a biocontrol agent, but also as a growth promoter. Different strains of $T$. harzianum and $T$. viride have shown increases in fresh and dry weights of lateral stems; also the increase in volume and dry weight of roots have been found in vegetables and other crops such as tobacco. In addition, two mechanisms of action have been identified with respect to the benefits of Trichoderma on plant growth. The first is an increase in nutrition through the solubilization and absorption of micro and macro nutrients, and the second is production-related growth promoters in plants, such as indol acetic acid [43]. Side effects of the antagonist found in this research are important because the productivity of cut flowers is measured by the number of lateral stems with flower. In plantations, it is possible to reach better performance with this treatment, even with some incidence of the disease. Marigold treatments, potassium phosphite and benomyl, were, 2.5, 2.3 and 2.4 side shoots per plant respectively, exhibiting difference versus the lowest average of 2.2 lateral shoots per plant. In addition, there is a confirmation of the effect of $F$. oxysporum on the development and growth of the plant when it does not receive any treatment.

\subsection{Root Dry Weight}

Treatment with marigold extract $120 \mathrm{~g} / \mathrm{L}$, had the best average of $6.5 \mathrm{~g}$ and it was statistically different from the control (Figure 5), but there was no difference between the marigold, potassium phosphite, benomyl and TRICHOD $^{\circledR}$ treatments. When the dry matter accumulation in the root and the average plant height are compared, similar behaviors are observed. A larger and well-structured root may provide greater anchorage and nutrient uptake to the plant, allowing better growth and development (Figure 5). F. oxysporum causes damage to the root, affects the amount of functional roots and decreases the amount of water absorbed by these. Some vascular pathogens are related to the inhibition in the production of root hairs, which reduces the absorption [11].

\subsection{Disease Incidence}

The disease did not show any external symptoms after six months of performing the inoculation. However, when the destructive sampling was done, it was found $100 \%$ incidence in all treatments. In the destructive sam- 


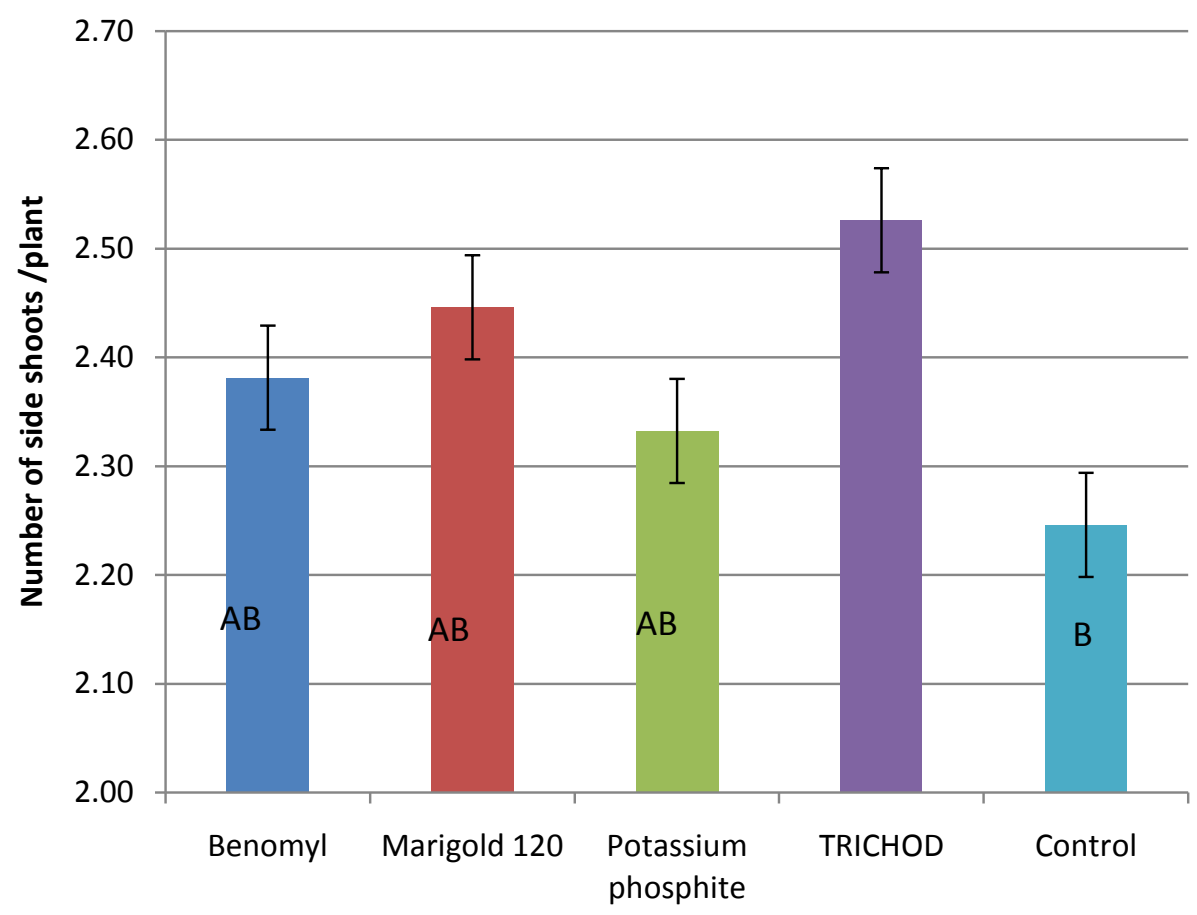

Figure 4. Effect of benomyl, marigold 120, potassium phosphite and TRICHOD on the number of side shoots of Leucadendrum plants. Means of 5 replications. Means with the same letter are not significantly different by the Tukey test.

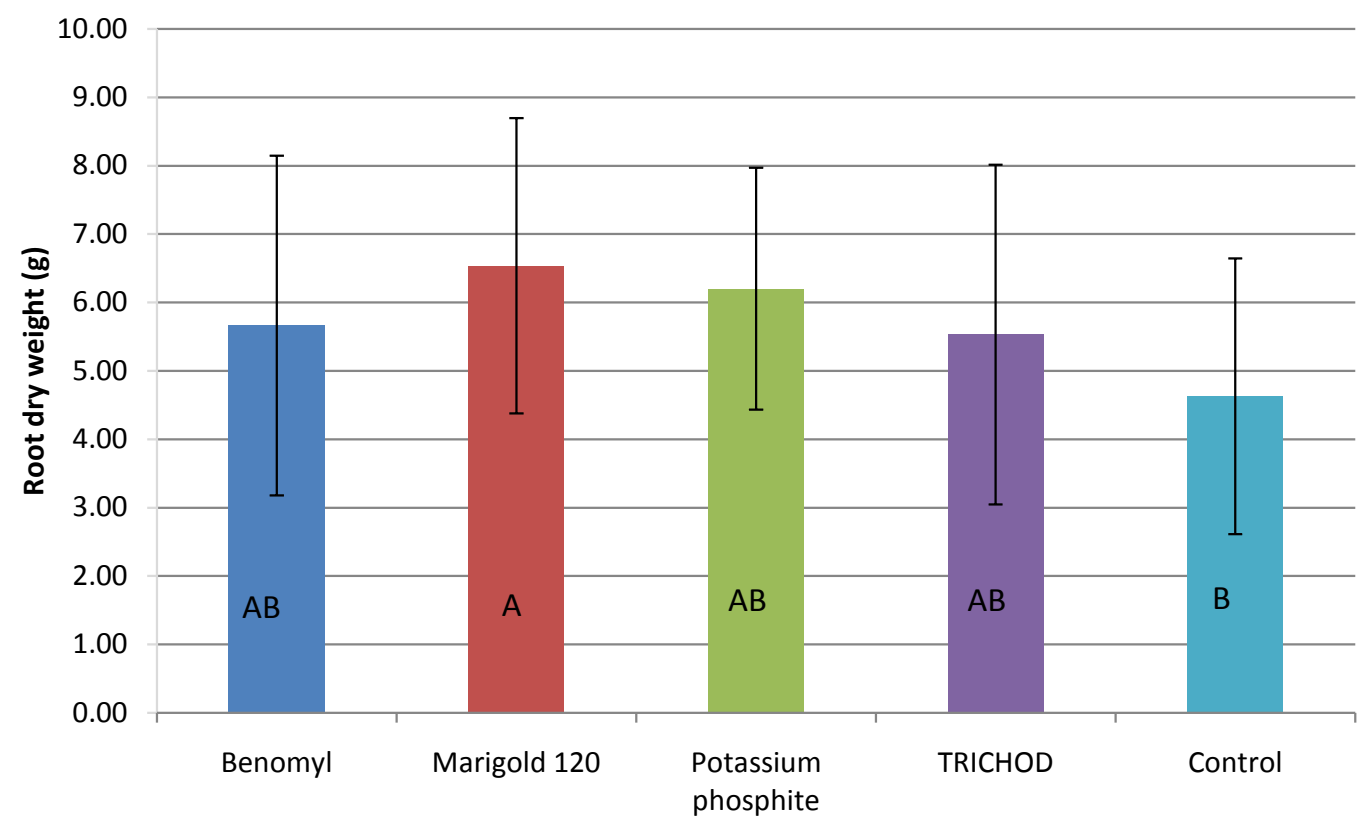

Figure 5. Effect of benomyl, marigold 120, potassium phosphite and TRICHOD on the root dry weight of Leucadendrum plants. Means of 5 replications. Means with the same letter are not significantly different by the Tukey test.

pling, it was evident the manifestation of symptoms in the vascular bundles, characterized by brown color around the xylem, extending from the base of the stem to the lateral side stems.

There were significant differences $(\mathrm{p} \leq 0.001)$ between treatments. The marigold extract presented the best efficacy against the disease, because reduced damage in $88.5 \%$, followed by TRICHOD, benomyl and potassium 
phosphite, which showed reductions in $86 \%$, $85 \%$ and $84 \%$, respectively. Although the treatment of potassium phosphite was not superior to marigold extract, it did show good plant height average (Figure 3), and it was able to reduce the development of disease. This result could be related to the induction of resistance mechanisms that allowed the plant to generate tolerance to the disease, and continue their growth and development. These results agree with the work of Monsalve et al., [44] who evaluated the effects of induced phytoalexins from phosphites in Oomycetes, Rhizoctonia solani and Botrytis cinerea.

Overall, marigold extract produced the best results in this investigation. Marigold has a number of compounds, such as sesquiterpenes, sesquiterpenoles, saponins and flavonoids that give certain anti-fungal properties. Martinez [22] mentions that flavonoids are aromatic compounds possessing anti-fungal activity against pathogens such as Penicillium sp and Rhizopus sp, amongst others. Phenolic compounds pervade pathogen cell membranes, resulting in leakage of cytoplasmic contents. According to Wedge et al. [23], sesquiterpenes are a family of more than 5000 compounds found primarily in members of the Compositae family. Sesquiterpenes have a broad spectrum of biological activity that plays an important role in the defense mechanisms of the plant. The same author found that sesquiterpene lactone had an inhibitory action against Colletotrichum, Phomopsis, Botrytis, but not against $F$. oxysporum isolated from Leucadendron sp.

Treatment with $T$. harzianum did not provide outstanding averages in the expression of growth traits, except the number of side shoots, which differed from the others; however, presented a significant reduction in lesion length, compared with the control. Possibly, the application of $T$. harzianum must be done before the infection, for greater efficiency, because, as demonstrated in the results obtained by Perez et al. [16], there was a complete control of $F$. oxysporum in banana plants treated with $T$. harzianum.

In contrast test was found that the length of the lesion was significantly higher in benomyl treatment versus marigold extract, indicating that the latter was better than the chemical treatment. Studies developed by Amini and Sidovich [25] indicate that better control of $F$. oxysporumf. sp. lycopersici was achieved with the application of pre-infection fungicide. This explains that the time of application affects the fungicide control responses of the disease. However, it is different with results obtained by Obreque [7], who obtained a $100 \%$ decrease in the Leucandendron disease when it was applied 30 days after inoculation. This result could be associated to the variability of $F$. oxysporum or the fungicide application method used.

\section{Acknowledgements}

To Universidad de Ciencias Aplicadas y Ambientales UDCA, for supporting this research.

\section{References}

[1] Salazar, I., Martínez, E., Peña, F., Cabezas, M. and Gómez, J. (2010) Identificación del agente causante de la marchitez de proteas (Leucadendronsp.). Rev. U.D.C.A. Act. \& Div. Cient., 13, 79-87.

[2] Littlejohn, G.M. (2001) The Challenges of Breeding Wild Flower Cultivars for Use in Commercial Floriculture: African Proteaceae. 20th International Eucarpia Symposium, Section Ornamentals, Strategies for New Ornamentals-Part I 552, 25-38.

[3] Moura, M. and Rodríguez, P. (2001) Fungal Diseases on Proteas Identified in Madeira Island. ISHS ActaHorticulturae 545: V International Protea Research Symposium, 265-268.

[4] Denman, S. (2001) Evaluation of a Stem Inoculation Technique for Assessing Resistance to Phytophora cinnamomi in Leucadendron y Leucospermun Cultivars. ISHS ActaHorticulturae, 545, 281-285.

[5] Brits, G. and Broembsen, S. (1985) Effects of Tillage on Heath Land Soil. Disturbance of a Natural Mountain Fybos System in the Southwestern Cape. South Africa. Soil and Tillage Research, 24, 29-45.

[6] Swart, L., Demman, S., Lamprecht, P. and Crous, P. (2001) Fusarium Wilt: A New Disease of Cultivated Protea in South Africa. Australasian Plant Pathology, 258, 156-161.

[7] Obreque, X. (2004) Evaluación de aplicaciones preinfección del fungicida benomylo y del biocontrolador Trichodermaharzianum en el control de Fusarium sp en Proteaceae. Escuela de Agronomía. Universidad de Talca, Chile. http://dspace.utalca.cl/

[8] Lubbe, C., Lamprecht, S., Van Niekerk, J. and Mostert, L. (2008) Molecular Characterization of Fusariumoxysporum Causing Wilt of Proteaceae. ISHS ActaHorticulturae, 805, 127-134.

[9] Dunne, C., Dell, B. and Hardy, G. (2003) “Sudden Death” in Proteas in the Southwest of Western Australia. ISHS ActaHorticulturae, 602, 39-44. 
[10] Benic, L.M. (1986) Pathological Problems Associated with Propagation Material in Proteaceae Nurseries in South Africa. ActaHort, 185, 229-236.

[11] Agrios, G.N. (2005) Plant Pathology. 5th Edition, Elsevier Academic Press, Amsterdam.

[12] Pandya, J.R., Sabalpara, A.N. and Chawda, S.K. (2011) Trichoderma: A Particular Weapon for Biological Control of Phytopathogens. Journal of Agricultural Technology, 7, 1187-1191.

[13] Intana, W. (2003) Selection and Development of Trichoderma spp. for High Glucanasa, Antifungal Metabolite Producing and Plant Growth Promoting Isolates for Biological Control of Cucumber Damping-Off Caused by Pythium spp. Ph.D. Thesis, Kasetsart University, Bangkok.

[14] González, J.C., Maruri, J.M. and González, A. (2005) Evaluación de diferentes concentraciones de Trichodermaspp contra Fusarium oxysporum agente causal de la pudrición de plántulas en papaya (Carica papaya L.) en Tuxpan, Veracruz, México. Revista UDO Agrícola, 5, 45-47.

[15] Ramezani, H. (2010) Antagonistic Effects of Trichoderma spp. against Fusariumoxyxporumf. sp. lycopersici Causal Agent of Tomato Wilt. Plant Protection Journal, 2, 167-173.

[16] Pérez, L., Batlle, A., Chacón, J. and Montenegro, V. (2009) Eficacia de Trichodermaharzianum A34 en el biocontrol de Fusarium oxysporumf. sp. cubense, agente causal de la marchitez por Fusariumo mal de Panamá de los bananos en Cuba. Fitosanidad, 13, 259-264.

[17] De Marcano, A., Vargas, D.N. and Pire, A.(2005) Efecto de extractos vegetales y fungicidas sintéticos sobre el crecimiento micelial in vitro de Sclerotiumrolfsiiy Thielaviopsisbasicola. Revista Facultad de Agronomía, 22, 315-323.

[18] Joseph, B., Dar, A. and Kumar, V. (2008) Bioefficacy of Plantextractsto Control Fusarium solani F. Sp. Melongenae Incitant of Brinjal Wilt. Global Journal of Biotechnology \& Biochemistry, 3, 56-59.

[19] Montasser, S.A., El-wahab, A.E., Abd-Elgawad, M.M., Abd-El-Khair, H., Koura, F.H. and Hammam, M.M. (2012) Role of Some Plant Extracts and Organic Manure in Controlling Tylenchus Semipenetrans Cobb in Vitro and in Vivo in Citrus. Journal of Applied Sciences Research, 8, 5415-5424.

[20] Gazim, Z., Moraes, C., Regina, S., Estivaletti, T. and Garcia, D. (2007) Antifungal Activity of the Essential Oil from Calendula officinalis L. (Asteraceae) Growing in Brazil. Brazilian Journal of Microbiology, 39, 61-63. http://dx.doi.org/10.1590/S1517-83822008000100015

[21] Acosta, L. (2006) Exploración de las propiedades antimicrobianas de extractos vegetales a partir de Calendula officinalis y Tropaeolummajus y su uso potencial en la industria de alimentos y cosmética. Trabajo de grado Universidad de La Sabana, Facultad de Ingeniería, Bogotá.

[22] Martínez, J.A. (2012) Natural Fungicides Obtained from Plants, Fungicides for Plant and Animal Diseases. In: Dhanasekaran, D., Ed., Fungicides for Plant Animal Diseases, InTech. http://www.intechopen.com/books

[23] Wedge, D., Galindo, J. and Macías, F. (1999) Fungicidal Activity of Natural and Synthetic Sesquiterpene Lactone Analogs. Phyotochemistry, 53, 747-757.

[24] Sonoda, R.M. (1977) Effect of Benomyl Drenches on Fusarium Crown Rot of Tomatões. Agricultural Research Center, Port Pierce, 1, 1-5.

[25] Amini, J. and Sidovich, D. (2010) The Effects of Fungicides on Fusariumoxysporumf. sp. lycopersicy Associated with Fusarium Wilt of Tomato. Journal of Plant Protection Research, 50, 172-178.

[26] Navarrete, R. and Acosta, R. (1999) Reacción de variedades de fríjol común a Fusarium spp. y Rhizoctoniasolani en el altiplano de México. Agronomia Mesoamericana, 10, 37-46.

[27] Nel, B., Steinberg, C., Labuschagne, N. and Viljoen, A. (2007) Evaluation of Fungicides and Sterilants for Potential Application Management of Fusarium Wilt of Banana. Crop Protection, 26, 697-705. http://dx.doi.org/10.1016/j.cropro.2006.06.008

[28] Silva, O.C., Santos, H.A.A., Dalla Pia, M. and May-De Mio, L.L. (2011) Potassium Phosphite for Control of Downy Mildew of Soybean. Crop Protection, 30, 598-604.

[29] Lobato, M.C., Olivieri, F.P., Daleo, G.R. and Andreu, A.B. (2010) Antimicrobialactivity of Phosphites against Different Potato Pathogens. Journal of Plant Diseases and Protection, 117, 102-109.

[30] Mogollón, A. and Castaño, J. (2011) Efecto de inductores de resistencia en plántulas de plátanodominicohartón (Musa balbisiana AAB) contra Mycosphaerella spp. Revista de la Academia Colombiana de Ciencias Exactas, Físicas y Naturales, 35, 463-471.

[31] Walters, D.R., Ratsep, J. and Havis, N.D. (2013) Controlling Crop Diseases Using Induced Resistance: Challenges for the Future. Journal of Experimental Botany, 64, 1263-1280. http://dx.doi.org/10.1093/jxb/ert026 http://jxb.oxfordjournals.org/content/64/5/1263.full.pdf+html

[32] Hofgaard, I., Ergon, A., Henriksen, B. and Tronsmo, A. (2010) The Effect of Potential Resistance Inducers on Deve- 
lopment of Microdochium majus and Fusarium culmorum in Winter Wheat. European Journal of Plant Pathology, 128, 269-281. http://dx.doi.org/10.1007/s10658-010-9662-5

[33] French, R. and Teddy, T. (1986) Métodos de Investigación Fitopatológica. IICA Costa Rica, 158-161.

[34] Barnett, L.H. (1998) Illustrated Genera of Imperfect Fungi. The American Phytopathological Society, St. Paul.

[35] Leslie, J.F. and Summerell, A. (2006) The Fusarium Laboratory Manual. Blackwell Publishimg, Ames. http://dx.doi.org/10.1002/9780470278376

[36] Cifuentes, J. (2000) Evaluación de la capacidad biocontroladora del hongo Trichodermahazianum cepa nativa Queule sobre Fusarium solani en tomate (Lycopersiconesculentum Mill). http://www.bionativa.cl/pdf/tesis/trichonativa/t13.pdf

[37] Muthomi, J., Riungi, W. and Wagacha, J. (2008) Management of Fusarium Head Blight of Wheat Using Antagonistic Microorganisms. http://www.tropentag.de/2007/abstracts/full/448.pdf

[38] Stefanova, M., Leiva, A., Larrinaga, L. and Coronado, M. (1999) Actividad metabólica de cepas de Trichodermaspp para el control de hongos fitopatógenos del suelo. Revista de la Facultad de Agronomía de la Universidad del Zulia, 16, 509-516.

[39] Selosse, M., Baudoin, E. and Vandenkoornhuyse, P. (2004) Symbiotic Microorganisms, a Key for Ecological Success and Protection of Plants. Comptes Rendus Biologies, 327, 639-648. http://dx.doi.org/10.1016/j.crvi.2003.12.008

[40] Santos, F., Souza, P., Resende, M., Pozza, E., Miranda, J., Ribeiro, P. and Manerba, F. (2007) Efeito de extratos vegetais no progresso de doenças foliares do cafeeiro orgânico. Fitopatologia Brasileira, 32, 59-63. http://dx.doi.org/10.1590/S0100-41582007000100009

[41] Zapata, R., Sanabria, M. and Rodríguez, D. (2003) Reducción del desarrollo de hongos fitopatógenos con extracto decardón lefaria (Cereusdeficiens). Interciencia, 28, 302-308.

[42] Hernández, A., Bautista, S. and Velásquez, M. (2007) Prospectiva de extractos vegetales para controlar enfermedades postcosecha hortofrutícolas. Revista Fitotecnia Mexicana, 30, 119-123.

[43] Avis, T., Gravel, V., Antoun, H. and Tweddell, R. (2008) Multifaceted Beneficial Effects of Rhizosphere Microorganisms on Plant Health and Productivity. Soil Biology \& Biochemistry, 40, 1733-1740. http://dx.doi.org/10.1016/j.soilbio.2008.02.013

[44] Monsalve, J., Viteri, S., Rubio, N. and Tovar, F. (2012) Efecto del fosfito de potasio en combinación con el fungicida metalaxyl + mancozeb en el control de mildeo velloso (Peronospora destructor Berk) en cebolla de bulbo (Allium cepa L.). Revista Facultad de Agronomía Universidad Nacional de Medellín, 65, 6317-6325. 
Scientific Research Publishing (SCIRP) is one of the largest Open Access journal publishers. It is currently publishing more than 200 open access, online, peer-reviewed journals covering a wide range of academic disciplines. SCIRP serves the worldwide academic communities and contributes to the progress and application of science with its publication.

Other selected journals from SCIRP are listed as below. Submit your manuscript to us via either submit@scirp.org or Online Submission Portal.
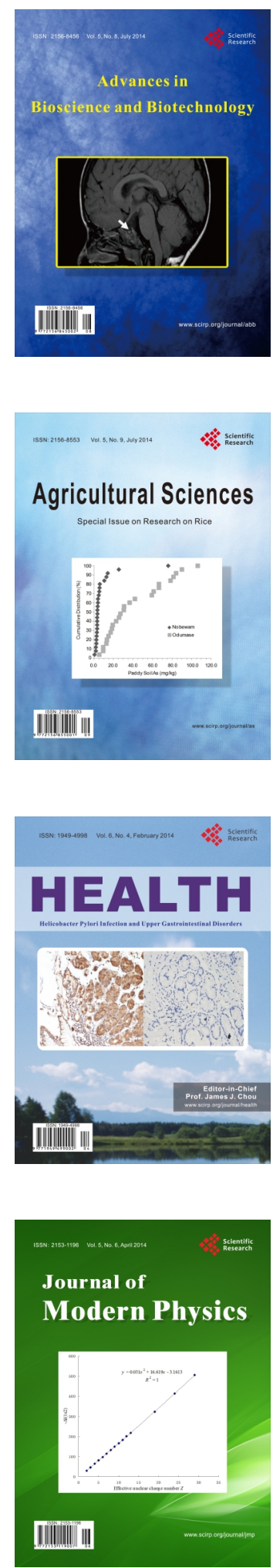
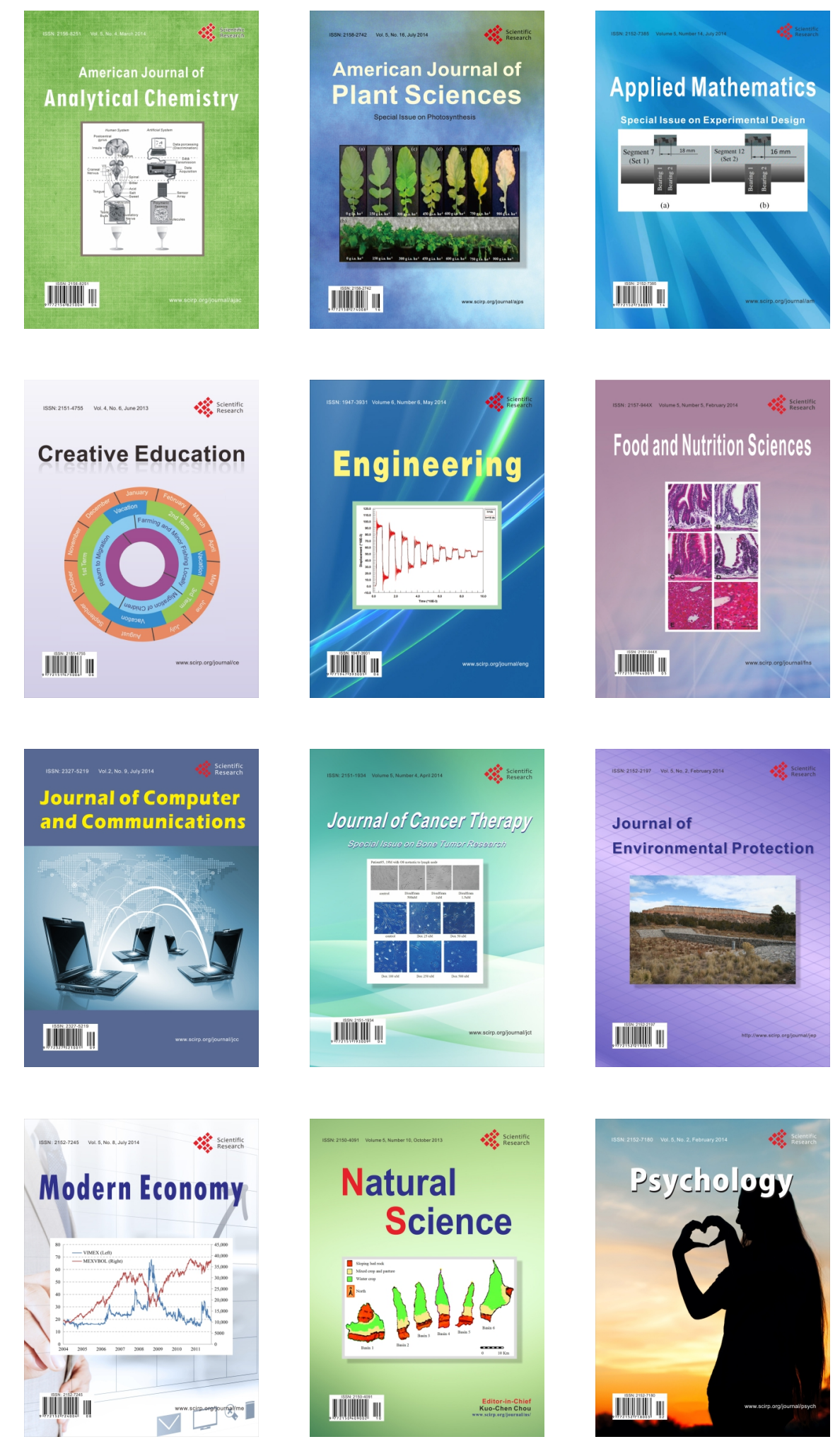